\title{
ASSOCIATION OF DNA FRAGMENTATION OF SPERMATOZOA AND THE SUCCESS OF ASSISTED REPRODUCTIVE TECHNOLOGY PROGRAMS
}

Received 20 July 2020;

Received in revised form 25 August 2020;

Accepted 28 August 2020

\section{Grigory Roitberg ${ }^{1,2}\left(\mathbb{D}\right.$, Yulia Vykhristyuk $^{1}$ (D), Elina Korovyakova ${ }^{3}$ (D), Tatyana Kokoreva ${ }^{3}$, Natalya Karaseva ${ }^{3}$ (D), Liubov Varekha ${ }^{3}$ (D), Maria-Francisca Alekseeva ${ }^{1}{ }^{D}$, Zinah Alshareeda ${ }^{3}$, Rebeka Hakobova ${ }^{3 \otimes}$ (i)}

\author{
1 Pirogov Russian National Research Medical University, Moscow, \\ 2 "Medicina" JSC, Moscow, \\ ${ }^{3}$ Peoples Friendship University of Russia (RUDN University), Moscow \\ Russia
}

rebecca_akobova@mail.ru

\begin{abstract}
The number of men with impaired sperm genetic material is steadily increasing, which is reflected in the increase in the number of assisted reproductive technology (ART) programs and their outcomes. This article presents an analysis of ART program success, depending on the proportion of DNA-sperm fragmentation. As a result, in couples with normal sperm counts $(n=43)$, the frequency of spontaneous abortions was twice lower compared to couples $(n=39)$, where the level of DNA fragmentation was increased $(p<0.05)$ Conclusions. The miscarriage in a spouse in the early stages (up to 12 weeks) is more common in couples with damaged sperm DNA.
\end{abstract}

KEY W ORDS - Male infertility, assisted reproductive technology (ART), DNA fragmentation, reproductive loss, spontaneous abortion.

\section{INTRODUCTION}

Every fifth married couple in Europe and every fourth couple in the world need medical help to manage infertility $[1,2]$. At the same time, the male factor of infertility is already found equally often with the female one [3]. Male infertility is provoked by many diseases: varicocele, inguinal hernia, sexually transmitted infections, genetic mutations, etc. [4, 5, 6, 7] these diseases often cause oxidative stress, damage and fragmentation of the DNA in germ cells, which is the cause of reduced sperm fertility [7]. In every third case, abnormalities in sperm and DNA fragmentation cannot be eliminated by medication. Therefore, married couples are forced to use assisted reproductive technologies (ART) to overcome childless marriage
[2]. Unfortunately, methods of infertility treatment using ART (IVF/ICSI) are successful only in 32\% of cases [8]. One of the factors of ART failures is the poor quality of sperm. Therefore, some authors suggest considering the level of sperm DNA fragmentation as a predictive criterion of ART outcomes [9].

To estimate the association of DNA fragmentation level in spermatozoa with the successful outcome of ARTprograms.

\section{METHODS}

We retrospectively evaluated the results of ART(ICSI) in 82 married couples. Inclusion criteria: male factor of infertility, absence of reproductive health pathology in the female partner. Exclusion criteria: varicocele, bad habits in men (smoking, alcohol, drugs).

All couples were divided into study groups:

Group 1: the percentage of DNA fragmentation of spermatozoa $<15 \%(n=43)$

Group 2: the DNA fragmentation in spermatozoa $>15 \%(\mathrm{n}=39)$

We performed semen analysis in all patients in accordance with WHO guidelines from 2010. We determined the level of DNA fragmentation of germ cells using the TUNEL method. The standard values of DNA fragmentation were considered to be less than $15 \%$. We evaluated the indicators of embryogenesis (formation of blastocysts at the stage of cultivation), the frequency of clinical pregnancies after the transfer of the native embryo in all married couples. We also recorded the level of reproductive losses.

The statistical analysis was performed using spreadsheets "EXCEL" and "STATISTICA 6.0". The significance of differences between quantitative indicators was assessed using the Mann-Whitney test. Differences were considered significant at $\mathrm{p}<0.05$.

\section{RESULTS}

We did not get significant differences in spermogram indicators in men of both study groups. Men of the first group had an average sperm concentra- 
tion of $4.9 \pm 3,2 \cdot 10^{6}$, and the second $-3.8 \pm 2,9 \cdot 10^{6}$ $(\mathrm{p}>0.05)$. The percentage of active-motile spermatozoa in patients of the first group was $17.2 \pm 4.8 \%$, in the second group - 14.5 $\pm 5.7 \%$; the percentage of normal spermatozoa was $4.6 \pm 2.3$ vs. $2.9 \pm 1.7$ ( $p>0.05)$. The level of DNA fragmentation of spermatozoa in men of the first group was significantly lower than in the second: $11.2 \pm 4.1 \%$ vs. $28.5 \pm 7.9 \%(\mathrm{p}<0.05)$. We demonstrate the effectiveness of ART depending on the level of DNA fragmentation in Table 1. Termination of embryo cultivation after 3 days significantly prevailed in the second group of the study $(\mathrm{p}<0.05)$. We found a direct correlation between reproductive losses (spontaneous abortion in early pregnancy) and the level of DNA fragmentation (Fig. 1)

\section{Table 1. The ART results in both monitoring groups}

\begin{tabular}{l|l|l|l}
\hline ART Effectiveness indicators & $\begin{array}{l}\text { The } 1^{\text {st }} \text { study } \\
\text { group n(\%) }\end{array}$ & $\begin{array}{l}\text { The } 2^{\text {nd }} \text { study } \\
\text { group } n(\%)\end{array}$ & $\mathrm{p}$ \\
\hline $\begin{array}{l}\text { Formation of blastocysts at } \\
\text { the stage of cultivation }\end{array}$ & $27(62,7 \%)$ & $17(43,5 \%)$ & $\mathrm{p}<0,05$ \\
\hline $\begin{array}{l}\text { Oncoming of clinical } \\
\text { pregnancy (\%) }\end{array}$ & $22(51,1 \%)$ & $15(38,4 \%)$ & $\mathrm{p}<0,05$ \\
\hline Undeveloped pregnancy & $3(6,9 \%)$ & $5(12,8 \%)$ & $\mathrm{p}<0,05$ \\
\hline Spontaneous abortion & $5(11,6 \%)$ & $8(20,5 \%)$ & $\mathrm{p}<0,01$ \\
\hline
\end{tabular}

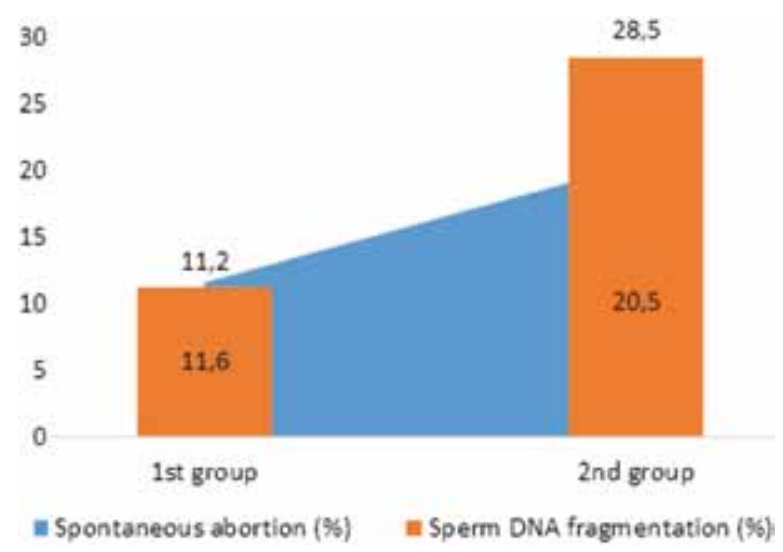

Fig. 1. Correlation between the level of DNA fragmentation (\%) and spontaneous abortions (\%) in both groups of patients

\section{DISCUSSION}

The birth of a healthy child undoubtedly depends on a woman's reproductive health. However, recently, there has been evidence that the frequency of pregnancies and embryo development is influenced by the quality of sperm $[8,9]$. It is especially important to exclude violations of the genetic material of sperma- tozoa in male infertility $[6,10]$. Palermo Gianpiero D. et al showed an inverse correlation between DNA fragmentation and sperm mobility [11]. Our study has indicated that there is a negative relation between the rate of DNA fragmentation of spermatozoa and the frequency of onset and development of clinical pregnancy in ART programs. Meta-analysis of the results of treatment of 2969 couples from 16 cohort studies showed a significant increase in the frequency of miscarriage in women who were fertilized with sperm with a high DNA fragmentation index (risk ratio $=2.16(1.54 ; 3.03), \mathrm{p}<0.00001)$ [9]. A DNAfragmentation test can show not only the proportion of damaged germ cells, but also the extent of breaks in the DNA molecule, which often stops the development of the embryo at any time. Ribas-Maynou J. et al. it was proved that the presence of DNA damage in two chains of the molecule leads to a high risk of miscarriage (specificity - 77.5\%) [12].

In couples with a high level of DNA fragmentation, additional selection of spermatozoa with an intact DNA chain must be used in order to achieve pregnancy in the ART program, after visual evaluation of progressive motility and native evaluation of germ cell morphology.

\section{CONCLUSIONS}

The miscarriage in the spouse in the early stages (up to 12 weeks) is significantly more common In couples where men have a high level of DNA fragmentation of spermatozoa than in couples with intact DNA of germ cells. The determination of DNA fragmentation in infertile men can be used as a predictive marker of fertility and the outcome of ART programs. Men with high levels of DNA fragmentation need treatment before planning ART.

\section{REFERENCES}

1. Patel A, Sharma P, Kumar P, Binu VS. Sociocultural Determinants of Infertility Stress in Patients Undergoing Fertility Treatments. J Hum Reprod Sci. 2018; 11(2): 172-179. doi: 10.4103/jhrs. JHRS_134_17

2. Kulchenko N.G. Prediction of success in assisted reproductive technology with the help of morphology of the testis. Research'n Practical Medicine Journal (Issled. prakt. med.). 2018; 5(4): 18-25. DOI: 10.17709/2409-2231-2018-5-4-2

3. Kulchenko N.G., Myandina G.I., Alhedjoj HaSAN. Assotiation-genetic study of polymorphism G-105A SEPS1 gene in male infertility. Research'n Practical Medicine Journal (Issled. prakt. med.). 2018; 5(2): 65-71. DOI: 10.17709/2409-2231-2018-5-2-7

4. Kulchenko N.G. Inguinal hernia repair and male health. Research and Practical Medicine Journal 
(Issled. prakt. med.). 2019; 6(3): 65-73. DOI: 10.17709/2409-2231-2019-6-3-6

5. Protasov A., Kulchenko N., Vinogradov I., NAVID M. The prevalence of patospermia in men after hernia repair. Archive Euromedica. 2019. T.9 (2): 108-110.

6. Myandina G., Kulchenko N., Alhejoj H., TARASENKo E. Disturbances of folate metabolism in men with infertility. Archive Euromedica. 2019. T.9 (2): 105-107. doi.org/10.35630/2199$885 \mathrm{X} / 2019 / 9 / 3.22$

7. Kulchenko N.G. Inflammation and male infertility. What's is common? RUDN Journal of Medicine. 2017; 21(4): 402-407.DOI: 10.22363/2313-02452017-21-4-402-407

8. Ferraretti AP, Goossens V, Kupka M, et al. Assisted reproductive technology in Europe, 2009: results generated from European registers by ESHRE. Hum Reprod. 2013;28(9):2318-2331. doi: 10.1093/ humrep/det278.
9. Robinson L, Gallos ID, Conner SJ. The effect of sperm DNA fragmentation on miscarriage rates: a systematic review and meta-analysis. Hum Reprod. 2012;27(10):2908-2917. doi:10.1093/humrep/des261

10. Myandina Gi, Hasan A, Azova MM, TARASEnKo EV, Kulchenko NG. Influence of GSTP1 gene polymorhism on decreased semen quality. Russian Open Medical Journal 2019; 8: e0411. DOI: $10.15275 /$ rusomj.2019.0411

11. Palermo Gianpiero D., Neri Queenie V., Cozzubbo Tyler, Rosenwaks Zev. Perspectives on the assessment of human sperm chromatin integrity. Fertility and Sterility. 2014;102(6):1508-1517. doi: 10.1016/j.fertnstert.2014.10.008.

12. Ribas-Maynou J, García-Peiró A, FernanDEZ-Encinas A. Double stranded sperm DNA breaks, measured by Comet assay, are associated with unexplained recurrent miscarriage in couples without a female factor. PLoS One. 2012;7(9):e44679. doi:10.1371/journal.pone.0044679 